\title{
The Study of Physical Properties of Dioscorea alata's Starch from Jambi Province
}

\author{
Ulyarti $^{\# 1}$, Lavlinesia ${ }^{\#}$, Dewi Fortuna ${ }^{\#}$ and Surhaini ${ }^{\#}$

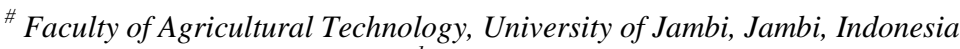 \\ E-mail: ${ }^{1}$ ulyarti@unja.ac.id
}

\begin{abstract}
Botanical origin of a plant is known to affect the physical characteristic of its tuber. This research was conducted to investigate the physical characteristic of starch obtained from Dioscorea alata tubers grown in Jambi Province. There were two cultivars used in this experiment: yellow and purple tuber. The tubers were extracted using three methods: control, soaking and steam blanching. Soaking was performed by soaking the small cut tubers in hot water at $60^{\circ} \mathrm{C}$ for 15 minutes while steam blanching was performed by steaming them at $\mathbf{1 0 0}^{\circ} \mathrm{C}$ for 5 minutes. The starches were examined for their colour parameter, swelling power (SP) and solubility. SP and solubility of starch were observed at several temperatures from 65 to $95^{\circ} \mathrm{C}$. Type of cultivar and the extraction method significantly affect $L^{*}, a^{*}$ and $b^{*}$ value of the starch. $S P$ at $65^{\circ} \mathrm{C}, 70^{\circ} \mathrm{C}$ and $75^{\circ} \mathrm{C}$ were found to be affected by both the type of cultivar $(\mathbf{p}<0.01))$ and the extraction method $(\mathbf{p}<0.01)$. Steam blanching was found to increase SP of purple and yellow cultivars. The solubility of starch was not affected by either the type of cultivar nor the extraction method
\end{abstract}

Keywords — Dioscorea alata; soakin; steam blanching; swelling power; solubility

\section{INTRODUCTION}

The source of starch used in food and non-food industry have to compete with starch source for staple food such as rice, corn, cassava, potato and wheat. The development of starch sources which are not staple food is becoming an alternative in order to fulfil the demand of starch for industry.

Dioscorea alata is potential starch source for this need. The starch content of Dioscorea alata's tuber reaches $80 \%(\mathrm{dw})$ [1]. Several researches about physicochemical properties of this starch have been published [2]-[7], however none has published the properties of the starch from the tuber of Dioscorea lata's plants which are cultivated in Jambi Province.

There are few areas in Jambi Province where Dioscorea alata cultivated by local people. The inland of Kerinci, Bangko and East Tanjung Jabung are few areas where this plant is grown well. This plant is considered very tough: grown well without any treatment and can grow in soil with limited nutrients. Some Dioscorea alata's tuber are purple and some are yellow. The tubers are utilised by local people only at difficult times where foods are lack.

Dioscorea alata's tubers contain polyphenoloxidase and peroxidase enzymes [8]. These enzymes change the tuber colour become darker. When this occur to yellow tuber, the colour change to brown whereas the purple tuber turns to nearly black. These enzymes are active soon after the tuber flesh is sliced. During the extraction of starch, the colour changes affects the white degree of the starch. Several treatments may be applied to prevent the colour change, one of them is using heat to inactivate the enzymes which cause the colour change [9], [10].

This research was done to determine the physical properties of Dioscorea alata's starch grown in Jambi Province and to determine the effect of heat applied during the extraction on the physical properties of the starch.

\section{MATERIALS AND METHODS}

\section{A. Materials}

The fresh Dioscorea alata's yellow tubers were harvested from Desa Trimulya, District of Rantau Rasau, East Tanjung Jabung whereas the purple tubers were harvested at District of Sungai Lumpur, Bangko.

\section{B. Methods}

There were 3 methods for starch extraction which produced "control starch", "soaked starch" and "steam blanched starch". The methods of starch extractions were done following method described by Nadia [7] with some modification. The procedures to obtained "control starch" was as follow. The tuber was cleaned from soil, washed, peeled, rewashed, and sliced into $2 \mathrm{~mm}$ to $3 \mathrm{~mm}$ slices. To remove mucus the slices were soaked in $15 \%$ table salt for 30 minutes and rewashed for 3 times. The tuber slices were 
smoothed using commercial blender and the slurries were passed through 170 mesh filter. The suspension obtained were precipitated for 6 hours. The presipitate was dissolved in water again to purify the starch. The wet starch was dried in air-oven at $50^{\circ} \mathrm{C}$ for 6 hours. The dry starch was sieved using 60 mesh filter and sealed packaged and kept at room temperature until further used. The procedures to obtain "soaked starch" was as follow. The tuber was cleaned from soil, washed, peeled, rewashed, and cut into $2 \times 2$ dice. The tuber dice were soaked in hot water $\left(60^{\circ} \mathrm{C}\right)$ for 15 minutes and sliced into $2 \mathrm{~mm}$ to $3 \mathrm{~mm}$ slices. The tuber slices were then treated similar to procedures to obtain "control starch". The procedures to obtain "steam blanched starch" was the same as procedure to obtain "soaked starch" with exception on the step soaking. The soaking in procedure to obtain "soaked starch" was replaced by steaming at $100^{\circ} \mathrm{C}$ for 5 minutes in procedure to obtain "steam blanched starch".

Color parameter $L^{*}, a^{*}$ dan $b^{*}$ were determined using simple digital imaging method $[11,12]$. Swelling power and solubility were measured using method described by Mir \& Don Bosco [13].

\section{Statistical Analysis}

Analysis of variance was conducted to determine the effect of extraction method on the physical characteristic of the starch. DMRT was used to determine the mean difference. Data analysis was performed using SPSSv 16.

\section{RESULT AND DISCUSSION}

The extraction of Dioscorea alata's tubers was easily done when most of the mucus had been washed out. The present of mucus inhibited the sedimentation of starch from suspension. Therefore in some cases the starch yield was fairly low (less than $10 \% \mathrm{wb}$ ). Therefore in this experiment we used tuber with low mucus content which can be identified from the color of the tubers. Purple tuber with white spots and light yellow tubers were identified to contain less mucus than dark purple tubers and dark yellow tubers. From these tubers the starch yield obtained was up to $14 \%$ (wb). This result is similar to starch yield reported before which ranged from $7-16 \%$ [7].

\section{A. Starch Color}

The starch extracted from purple tuber had lighter color than the starch extracted from yellow tuber (Fig. 1). The degree of whiteness is shown by the value of $L^{*}$ (lightness). The higher whiteness of the starch, the higher value of $L^{*}$ up to 100 . The color of starch is the sign for purity, where the value of $L^{*}$ is expected to be higher than 90 [14]. Dioscorea alata's starch from purple tuber had value of $L^{*}$ close to 100 whereas the starch from yellow tuber had $L^{*}$ value $81-92$ (Table I). This is an indication that the procedures to extract starch from purple tuber was acceptable to obtain preferable purity.

Steam blanching and soaking the purple tuber in warm water decreased the value of $L^{*}$ indicating the leaching of tuber's pigments onto starch during both treatments. Similar decrease of $L^{*}$ value of rice starch had been reported by Mir \& Don Bosco [13] and Falade \& Christopher [15]. Different result was found for yellow tuber where soaking yellow tuber in warm water increased the value of $L^{*}$ but steam blanching decreased the value of $L^{*}$. Similar results were observed for $a^{*}$ and $b^{*}$ values. These indicate that the pigments in yellow tubers were dissolved in water and the higher the temperature the more pigment was released and decreased starch purity.

\section{B. Swelling Power}

Swelling power (SP) is known to relate to amylose content, water holding capacity of starch molecules, hydrogen bond, and degree crystallinity of the starch granule. In this research, the water contents of starch were not significantly different $(\mathrm{p}>0.05)$ ranging from 8 to $11 \%(\mathrm{wb})$ (Table 2). Swelling power of the starches from present experiment was in the range 2 to 10 for purple tuber and 2 to $14(\mathrm{~g} / \mathrm{g})$ for yellow tuber. This results were lower than previously published where SP D. alata was in the range 3 to $17(\mathrm{~g} / \mathrm{g})[5]$.

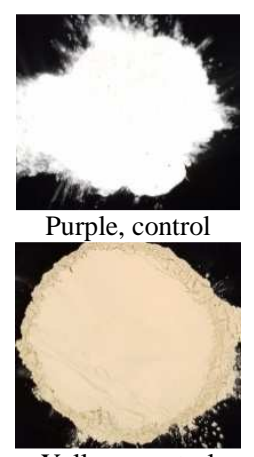

Yellow, control
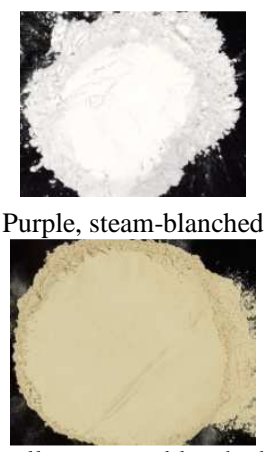

yellow, steam-blanched

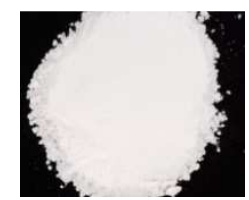

Purple, soaked

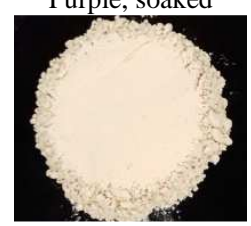

yellow, soaked
Fig. 1 Starches from the extraction of Dioscorea alata's tuber using 3 methods of exctraction

TABLE I

THE AVERAge OF COLOR PARAMETERS (CP)

\begin{tabular}{|c|c|c|c|c|}
\hline \multirow{2}{*}{ Kultivar } & CP & Control & $\begin{array}{c}\text { Steam- } \\
\text { Blanched }\end{array}$ & Soaked \\
\hline \multirow{3}{*}{ Purple } & $\mathrm{L}^{*}$ & $99.4 \pm 0.55^{\mathrm{a}}$ & $98.6 \pm 2.07^{\mathrm{a}}$ & $93 \pm 0.71^{\mathrm{b}}$ \\
\cline { 2 - 5 } & $\mathrm{a}^{*}$ & $0.0 \pm 0.00^{\mathrm{b}}$ & $-0.4 \pm 0.55^{\mathrm{b}}$ & $1.2 \pm 0.45^{\mathrm{a}}$ \\
\cline { 2 - 5 } & $\mathrm{b}^{*}$ & $0.2 \pm 0.45^{\mathrm{c}}$ & $2.2 \pm 0.84^{\mathrm{a}}$ & $1.2 \pm 0.45^{\mathrm{b}}$ \\
\hline \multirow{3}{*}{ Yellow } & $\mathrm{L}^{*}$ & $88.4 \pm 0.89^{\mathrm{b}}$ & $81.8 \pm 0.45^{\mathrm{c}}$ & $92.2 \pm 0.84^{\mathrm{a}}$ \\
\cline { 2 - 5 } & $\mathrm{a}^{*}$ & $5.4 \pm 0.55^{\mathrm{a}}$ & $0.4 \pm 0.55^{\mathrm{c}}$ & $4.6 \pm 0.55^{\mathrm{b}}$ \\
\cline { 2 - 5 } & $\mathrm{b}^{*}$ & $18.2 \pm 0.45^{\mathrm{b}}$ & $21 \pm 0.71^{\mathrm{a}}$ & $12.8 \pm 0.45^{\mathrm{c}}$ \\
\hline
\end{tabular}

Means with the same superscript in the same row were not significantly different $(p>0.05)$

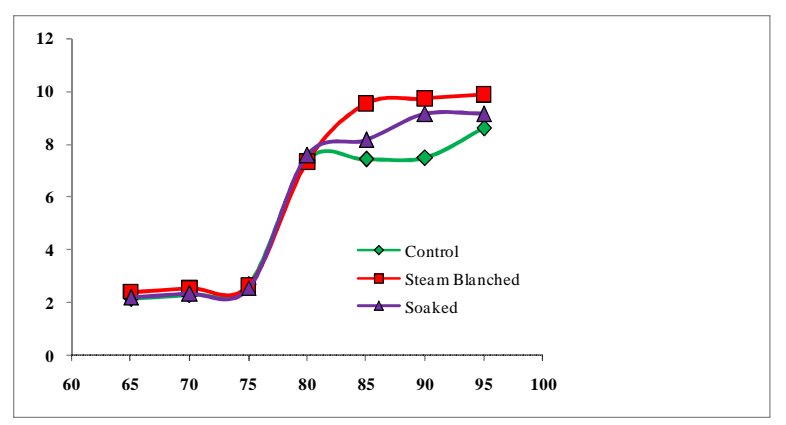

Fig. 2 Swelling power of starch from Dioscorea alata's purple tubers 


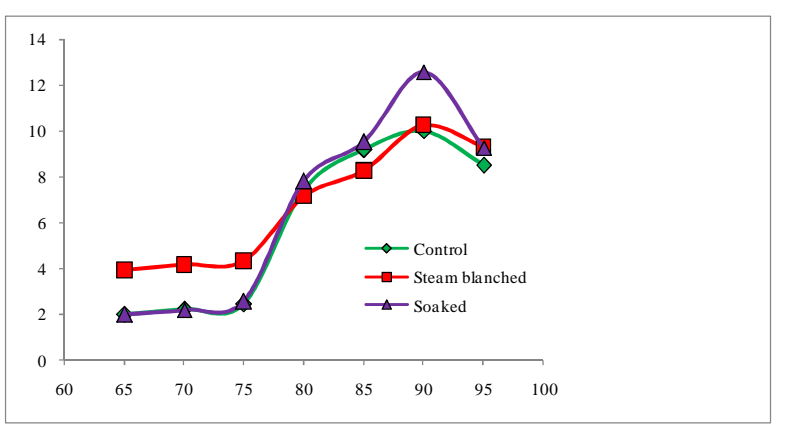

Fig. 3 Swelling power of starches from Dioscorea alata's yellow tubers

Swelling power was increased as the temperature increased to $95^{\circ} \mathrm{C}$ for purple tuber and to $90^{\circ} \mathrm{C}$ for yellow tuber. The graphs of both purple and yellow tubers's starch were similar: drastic increase at $80^{\circ} \mathrm{C}$ as shown in Figure 2 and 3. Decrease in $\mathrm{SP}$ at $95^{\circ} \mathrm{C}$ were observed for starches from yellow tubers extracted using all methods. None of such decrease was observed for starches from purple tubers.

Methods of extraction significantly affect $(\mathrm{p}<0.05)$ SP of starches from both purple and yellow tubers. Duncan test showed that SP of control and soaked starches from purple and yellow tubers were not signficantly different. Steam blanching increased SP starches of both purple and yellow Dioscorea alata's tubers at temperatures below $80^{\circ} \mathrm{C}$ (Table II) but no difference was observed after $80^{\circ} \mathrm{C}$. SP is a parameter which shows the ability of starch to absorb water (undergo hidration) and to swell [13]. Higher SP indicates weaker intra and intermoleculer bonds inside granules which enable water to penetrate the granules [16]. Steam blanching at $100^{\circ} \mathrm{C}$ for 5 minutes may have weaken intra and intermoleculer bonding in the starch granules and deformed crystal region in the granules. During heating, water can easily penetrate the granules in which the inter and intramoleculer bonding have been weaken. Treatment using heat and moisture is known to decrease relative crystallinity of starch granules [17], this can be used to explain the effect of steam blanching treatment in this experiment. However, further heating may change crystalline structure in the granules to become more compact result in a decrease in starch ability to absorb water [1],[5].

Results from ANOVA showed that there was a highly significant effect of type of cultivars on starch's SP at $65^{\circ} \mathrm{C}$ $(\mathrm{p}=0.0143), 70^{\circ} \mathrm{C}(\mathrm{p}=0.0099)$ and $75^{\circ} \mathrm{C}(\mathrm{p}=0.006)$. Starch from yellow tuber has higher maximum SP than starch from purple tuber. Maximum SP of yellow tuber's starch was achieved at $90^{\circ} \mathrm{C}$, while maximum SP of purple tuber's starch was at $85^{\circ} \mathrm{C}$. The lower SP may related to the presence of crystalline area which formed along with the association between long amilopectin chains [18], [19].

\section{Solubility}

Temperature had significant effect on the starch solubility $(\mathrm{p}<0.01)$. The solubility of starch from Dioscorea alata purple and yellow tubers increases as temperature increases. These results were similar to common starch [14], [20], [21]. However, starches from present study had very low solubility (the highest was $3.9 \%$ pada suhu $75^{\circ} \mathrm{C}$ ) compare to other Dioscorea's starch from different studies such as Dioscorea nipponica (5.18\%), Dioscorea alata (16.19\%), Dioscorea opposite (10.25\%), dan Dioscorea bulbifera $(5.79 \%)$. The value from present study was a litte bit higher than solubility of Dioscorea septemloba's starch (3.59) at the same temperature [5].

Solubility is related to the presence of water soluble molecules such as amylose [22]. The higher amylose content the higher solubility. However, this is not always true. There was starch whose higher amylopectin content had higher solubility [13]. This may occur due to hydrogen bonding is easily weaken at granules with higher amylopectin content. During heating, the insoluble portions undergo swelling which in turn weaken hydrogen bonding infrastucture inside the granules. This allows some starch fragments to be dissolved.

In this present study, methods of extraction did not affect solubility. This showed that water and heat used in this study were only able to affect swelling ability of amylopectin but not to deform starch granules infrastucture which produced soluble starch fragments.

TABLE III

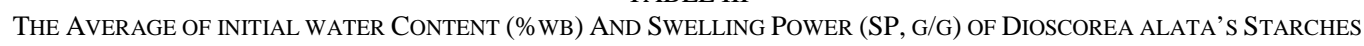

\begin{tabular}{|c|c|c|c|c|c|c|}
\hline \multirow{2}{*}{ Properties } & \multicolumn{3}{|c|}{ Purple Tuber } & \multicolumn{3}{c|}{ Yellow Tuber } \\
\cline { 2 - 7 } & Control & $\begin{array}{c}\text { Steam } \\
\text { Blanched }\end{array}$ & Soaked & Control & $\begin{array}{c}\text { Steam } \\
\text { blanched }\end{array}$ & Soaked \\
\hline SP $65^{\circ} C$ & $2.13 \pm 0.28^{\mathrm{a}}$ & $2.40 \pm 0.22^{\mathrm{b}}$ & $2.18 \pm 0.21^{\mathrm{a}}$ & $2.00 \pm 0.08^{\mathrm{a}}$ & $3.93 \pm 0.24^{\mathrm{b}}$ & $1.97 \pm 0.09^{\mathrm{a}}$ \\
\hline $\mathrm{SP} 70^{\circ} \mathrm{C}$ & $2.30 \pm 0.03^{\mathrm{a}}$ & $2.54 \pm 0.00^{\mathrm{b}}$ & $2.32 \pm 003^{\mathrm{a}}$ & $2.20 \pm 0.03^{\mathrm{a}}$ & $4.16 \pm 0.52^{\mathrm{b}}$ & $2.19 \pm 0.09^{\mathrm{a}}$ \\
\hline $\mathrm{SP} 75^{\circ} \mathrm{C}$ & $2.68 \pm 0.02^{\mathrm{a}}$ & $2.64 \pm 0.03^{\mathrm{s}}$ & $2.55 \pm 0.31^{\mathrm{a}}$ & $2.44 \pm 0.04^{\mathrm{a}}$ & $4.32 \pm 0.27^{\mathrm{b}}$ & $2.57 \pm 0.27^{\mathrm{a}}$ \\
\hline Water content & $11.75 \pm 0.46^{\mathrm{a}}$ & $11.30 \pm 0.96^{\mathrm{a}}$ & $11.79 \pm 0.19^{\mathrm{a}}$ & $11.46 \pm 1.79^{\mathrm{a}}$ & $8.80 \pm 0.67^{\mathrm{a}}$ & $11.44 \pm 2.49^{\mathrm{a}}$ \\
\hline
\end{tabular}

Numbers presented are the average of two readings and the deviations

Means with the same superscript in the same row were not significantly different $(\mathrm{p}>0.05)$ 


\section{CONCLUSIONS}

Starches from purple and yellow tubers of Dioscorea alata growm in Jambi Province have different physical properties. Starch from purple tubers has higher $\mathrm{L}^{*}$ value close to 100 than starch from yellow tubers. Starch from purple tubers has lower swelling power but higher solubility than starch from yellow tubers. Steam blanching increased swelling power of starch from both purple and yellow tuber. Both type of cultivars and method of extraction did not affect starch solubility.

\section{ACKNOWLEDGMENT}

The authors would like to thank Dean of Agricultural Technology University of Jambi for funding this research through PNBP Fakultas scheme. Thanks to Setiawati, Nuzula, Yuni Astrini, Dewi Sartika, and Meika Pestaria who did the technical works.

\section{REFERENCES}

[1] Hoover, R. "Composition, molecular structure, and physicochemical properties of tuber and root starches: a review". Carbohydrate polymers, 45, 253-267, 2001

[2] Mali S, Ferrero C, Redigonda V, Beleia AP, Grossmann MVE, Zaritzky NE. "Influence of PH and hydrocolloid addition on yam (Dioscorea alata) starch pastes stability". Lebensm-Wiss.u-Technol., vol. 36 , pp. 475-481, 2003

[3] Wickramasinghe HAM, Takigawa S, Matsuura-Endo C, Yamauchi H, Noda T. "Comparative analysis of starch properties of different root and tuber crops of Srilangka". Journal of Food Chemistry, vol.112, pp. 98-103, 2009.

[4] Indrasuti, E., Harijono, dan Susilo, B. "Karakteristik tepung uwi ungu (Dioscorea alata) yang direndam dan dikeringkan sebagai bahan edible paper". Jurnal Teknologi Pertanian, vol.13, pp.169-176, 2012.

[5] Jiang Q, Gao W, Li X, Xia Y, Wang H, Wu S, Huang L, Liu C, Xiao P. "Characterizations of starches isolated from five different Dioscorea L species". Food Hydrocolloids, vol.29, pp.35-41, 2012.

[6] Perez E, Rolland-Sabate A, Dufour D, Guzman R, Tapia M, Raymundez M, Ricci J, Guilois S, Pontoire B, Reynes M, Gilbert O. "Isolated starches from yams (Dioscorea sp) grown at the Venezuelan Amazons: Structure and functional properties". Vol.98, pp.650-658, 2013.

[7] Nadia, L, Wirakartakusumah, A, Abdarwulan N, Purnomo EH, Koaze H, Noda T. "Characterization of physicochemical and functional properties of starch from five yam (Dioscorea Alata) cultivars in Indonesia". International journal of Chemical Engineering and Application, vol.5, pp.489-496, 2014.

[8] Krishnan JG, Padmaja G, Moorthy SN, Suja G, Sajeev MS. "Effect of pre-soaking treatments on the nutritional profile and browning index of sweet potato and yam flours". Innovative Food Science And Emerging technologies, vol.11, pp.387-393, 2010.

[9] Akissoe, N., Hounhouigan, J., Mestres, C., \& Nago, M. "How Blanching and Drying Affect the Colour and Functional Characteristics of Yam (Dioscorea Cayenensis-rotundata) Flour". Food Chemstry, vol.82, pp.257-264, 2003

[10] Akissoe N, Hounhouigan J, Mestres C, Nago M. "Effect of tuber storage and pre- and post-blanching treatments on the physicochemical and pasting properties of dry yam flour". Journal of Food Chemistry. 85,141-149, 2004

[11] Yam, K., \& Papadakis, S. "A Simple Digital Imaging Method for Measuring and Analysing Color of Food Surfaces". Journal of Good Engineering, 61, 61(137-142), 137-142, 2004

[12] Leon, K., Mery, D., Pedreschi, F., \& Leon, J. "Color Measurement in L*a*b* units from RGB Digital Images". Food Research International, 39, 1084-1091, 2006

[13] Mir Ahabir Ahmad, Don Bosco Sowriappan John. "Cultivar difference in physicochemical properties of starches and flours from temperate rice of Indian Himalayas". Food Chemistry, 157, 448-456, 2014

[14] Boudries N, Belhaneche A, Nadjemi B, Deroanne C, Mathlouthi M, Roger B, Sindic M. "Physicochemical and functional properties of starches from sorghum cultivated in the Sahara of Algeria". Carbohydrate polymers, 78, 475-480, 2009

[15] Falade KO, Christopher AS. "Physical, functional, pasting and thermal properties of flours and starches of six Nigerian rice cultivars". Food Hydrocolloids. 44, 478-490, 2015

[16] Hoover R and Manuel H. "The effect of heat moisture treatment on the structure and physicochemical properties of normal miaze, waxy maize, dull waxy maize, and amilomaize V starches". Journal of Cereal Science, vol. 23, pp. 153-162, 1996

[17] Hoover R, Gunaratne A. "Effect of heat-moisture treatment on the structure and physicochemical properties of tuber and root starches". Carbohydrate Polymers. 49, 425-437, 2002

[18] Hughes T, Hoover R, Liu Q, Donner E, Chibbar R, Jaiswal S. "Composition, morphology, molecular structure, and physicochemical properties of starches from newly released chickpea (Cicer arietinum L.) cultivars grown in Canada". Food Research International. 42, 627-635, 2009

[19] Wang S, Gao W, Chen H, Xiao P. "Studies on the morphological, thermal and crystalline properties of starches separated from medicinal plants". Journal of Food Engineering. 76, 420-4, 2006

[20] Yuan Y, Zhang L, Dai Y, Yu J. "Physicochemical properties of starch obtained from Dioscorea nipponica Makino comparison with other tuber starches". Journal of Food Engineering. 82, 436-442, 2007

[21] Zeng S, Wu X, Lin S, Zeng H, Lu X, Zhang Y, Zheng B. "Structural characteristics and physicochemical properties of lotus seed resistance starch prepared by different methods". Food chemistry, 186, 213-222, 2015

[22] Tester RF, Morrison WR. "Swelling and Gelatinisation of cereal starches. I. Effects of amylopectin, amylose, and lipids". Cereal Chem. 67(6), 551-557, 1990 